\title{
THE CANONS OF NEPALI WRITING IN ENGLISH
}

\section{Min Pun *}

\begin{abstract}
After Laxmi Prasad Devkota pioneered Nepali writing in English in the 1950s, Mani Dixit, Tek Bahadur Karki, Abhi Subedi, Padma Prasad Devkota, D.B. Gurung, Laxmi Devi Rajbhandari and a few others continued to write in English during the 1960s, 70s and 80s. But Nepali writing in English gained its momentum with the publication of Samrat Upadhyay's Arresting God in Kathmandu in 2000 and Manjushree Thapa's The Tutor of History in 2001. They were followed by a group of other aspiring Nepali writers who emerged with their works in English that took over the global readership. Therefore, this paper argues that Nepali writing in English has achieved its canonical status with Laxmi Prasad Devkota, Samrat Upadhyay and Manjushree Thapa as canons of Nepali writing in English.
\end{abstract}

Key words: Nepali writing in English; the 1990 political change; the first generation, the second generation Nepali writers; literary canon

\section{INTRODUCTION}

With the 1990 political change in Nepal, a group of enthusiastic Nepali writers emerged with significant English writings, taking over the wider readership. They appeared with new themes and techniques of writing as Manjushree Thapa (2009) claims, "In them we glimpse the immense volatility - and the many struggles and gains - of Nepal's past fifteen years" (p. vii). Some examples include Sushma Joshi, Rabi Thapa, Sheeba Shivanagini Shah, Ajit Baral, Richa Bhattarai, M.K. Limbu, and Aditya Man Shrestha. This trend indicates that the corpus of Nepali writing in English, which is "a much newer phenomenon" (Hutt, 1993, p. 5), has been rapidly expanding since the restoration of democracy in Nepal. In this way, they paved a way for Nepali writing in English and inspired a group of aspiring Nepali writers to follow their footsteps.

Nepali English writing now stands by itself as a body of literature and has expanded its horizons to the global arena. In particular, Samrat Upadhyay and Manjushree Thapa have made "important contributions to

* Dr. Pun is Associate Professor in English, Prithivi Narayan Campus, Pokhara, TU. 


\section{THE CANONS OF NEPALI WRITING IN ENGLISH}

the field of Nepali English writing" (Uprety, 2011, p. 222) by publishing internationally acclaimed works in literature. Now, it has reached new heights after their publication. Should we now start debating the canon of Nepali writing in English? Such question leads to other questions: Which Nepali writers and works in English should be included in the canon? For instance, Mani Dixit, Tek Bahadur Karki, Abhi Subedi, Peter J. Karthak, Ramesh Shrestha, Padma Prasad Devkota, D.B. Gurung, Laxmi Devi Rajbhandari, Deepak S. Rana, Kesar Lall, Dhruba K. Deep and M. L. Karmacharya have come a long way from 1960s, 70s and 80s, and have continued to write even today. If there is a canon in Nepali writing in English as such, should they be included in it?

Since Nepali writing in English has begun to function like the western canon, the works of English by Nepali writers have attracted a wider readership (Pun, 2013b, p. 117). For instance, Upadhyay and Thapa are familiar with academic circles of the west. This is because of their regular presence there. They have also contextualized the question of literary canon in Nepali writing in English.

\section{THE QUESTION OF CANON}

There is a question of canon What canon is! The simple answer is that 'canon' is a list of major authors or works of literature; in the past, it referred to philosophical, political, and religious texts considered as fundamental by a particular group or society. More specifically, the term 'canon' refers to writers or works that either included in literature syllabi or textbooks, or often appear in the compilations of "the history of literature, bibliographies, and literary criticism" (Wilczek, 2012, p. 1687). It means that the canon can be defined as organized set of characteristics possessed by a writer, or his or her work that determine the status of canonicity. However, the canon has come to be viewed by many as "the expression of cultural authority created by other people influential in the past"; it has been defined as "the space of cultural conflict" and as "debatable ground, the ground of the battle between various groups, practices and institutions" (as cited in Wilczek, 2012, p. 1687). Such definitions of the term can have one of two outcomes: one, a new canon is established and two, the concept of a canon is put into question. When a work of literature is categorized as canonical, it needs to be assessed by specific validity. Such a work gains status as an official inclusion into a group of writers, or works that are widely studied 
and respected. But the issue of whether a writer or a work is canonized remains a personal opinion.

After 1990, Nepali fiction writers Samrat Upadhyay, Manjushree Thapa, Sheeba Shah and Sushma Joshi are some of the writers in English who are part of the new generation of writers. Their works have taken over in the wider world and have carried "a lot of implications in Nepalese linguistic and ELT landscapes" (Karn, 2012, p. 37). In this way, with many writers bringing out new books, the corpus of Nepali English literature is rapidly expanding its horizons to the global arena. There still arises another question: Do they have also provided a serious matter for the discussion of whether Nepali writing in English has attained the canonical position?

\section{HISTORY IN THE MAKING}

English writing in Nepal dates back some six or seven decades. It was in the 1950s that Laxmi Prasad Devkota started writing in English. It was the time when Nepal had just emerged out from a century of isolation from the outside world. In addition, the teaching and learning of English was confined to a certain group of elites who were not interested in English writing. It was only in 1959 that English was added to the higher education curriculum. Most of the works in English in Nepal were the translated texts until the end of 1980s; very few tried their hands in creative writing in English.

Laxmi Prasad Devkota published three works of English: Bapu and Other Sonnets, Shakuntala and The Lunatic and Other Poems, which were originally written in English during the 1950s. His Bapu and Other Sonnets contains fifty-nine sonnets, which were written when he was in exile in India in 1949. Out of them, thirty eight were written in the memory of Mahatma Gandhi (popularly known as Bapu) who led the Indian Movement for Independence. His epic Shakuntala, a story from the Hindu mythology Mahabharata, represents the eastern culture, values and heritage. His poetry book The Lunatic and Other Poems includes thirty poems translated by the poet himself, dealing with the "variety of themes, however, to be more specific, the concept of 'Nature', sharp satire on socio-political situation and caste based discrimination, love and memory, desire for change/revolution, pride of nationality and importance of food formulate the major themes of these poems" (Sharma, 2011, p. 47). 
Devkota has also written criticism, stories and essays in English. In fact, he has laid the foundation of writing literary works in English. Some of his English translations were also published in Indreni, the poetry magazine of Kavya Pratisthan (the predecessor of Nepal Academy). The main purpose of his writing in English, as he argued, is "because of its extensive use in India, especially in the Deccan and the different parts of Asia and world" (as cited in Subedi, 1999, p. iii). Thus, his writing in English was the need of the hour as Nepal opened its doors to the world after 1950; it became free from the autocratic Rana rule and democracy was the system of the nation. According to Krishna Chandra Sharma (2011), Devkota was "true to express his individual self as a poet as well as committed to the national spirit as a conscious citizen and performed a commendable role in the establishment of democracy in Nepal" (p. 42). Apart from this, he also helped establish Tribhuvan University and contributed to the promotion of Nepali language and literature.

During the 1950s, Devkota was the sole writer to start creative writing in English, which was a movement in English writing. His works in English were "directly linked to Nepali modernity" and were "closely related to English education and English as a medium of literary production in Nepal" (Sharma, 2011, p. 42). The context for creative writing in English was quite favourable at that time because Rabindra Nath Tagore, Mulkraj Anand and Nirad C. Chaudahri were his contemporaries in India. However, the context for creative writing in English was different in India and in Nepal. In India, English became its official and second language and it had the legacy of British Raj in India. English was introduced in India by the colonial rule with a number of educational institutions that were established throughout the country. Even when the British rule ended, it left behind the language. But in Nepal, English was the second or even the third language and it had no direct contact with the native speakers of English. Devkota, in spite of this lacking in the linguistic context, saw great potentiality in this language through which he and his native writers could enter into the readership in the wider world.

It is important to ask a question here: Is Devkota the canon or just the pioneer of Nepali writing in English? Devkota definitely pioneered the first generation of Nepali writers in English. He should also be considered the sole canon of the first generation Nepali writing in English. Followed 
by him were other Nepali writers in English. They include Mani Dixit, Tek Bahadur Karki, Ramesh Shrestha, Abhi Subedi and Peter J. Karthak during the 1960s and 70s. Only three thin pioneering collections of poems originally written in English published. The first was Sweet Steeple by Tek Bahadur Karki and was published in 1966. It was in the single volume. The second was Manas: A Collection of Poems, an anthology of poems published in 1974, by the Nepali poets Ramesh Shrestha, Abhi Subedi, and Peter J. Karthak. The book consisted of twenty one poems. Mani Dixit published his non-fiction work Come Tomorrow: Gurkhas \& Their Land in 1980. The book is about Gurkha soldiers who served for Indian and British Army.

During the 1970s and 80s, a group of writers joined them. They were Padma Prasad Devkota, Greta Rana, Kesar Lall, Prakash A. Raj, Kesang Tseten, Manju Kachuli, Shailendra K. Singh, Yuyutsu R.D. Sharma, Pallav Ranjan, Para Limbu, Laxmi Devi Rajbhandari and D.B. Gurung who also belonged to the first generation Nepali writers in English. Their works still appear in English though the tradition of writing in English after Laxmi Prasad Devkota suffered much until the late 1980s. The lovers of English works had to wait for two decades or so. A few works in English appeared, however; mostly they appeared in English translations. Some of the creative works of the time include H.M. Ansari' The Embrace of Twilight (1986), Bandana Shrestha's Groping in the Dark Dawn (1988), Greta Rana's Distant Hills and Right As It Is (1977), and Mani Dixit's Two Towards Kantipur (1977). This list is not exhaustive.

In 1990, there was a mass protest against the Panchayat government in Nepal. The movement aimed at restoring democracy. Opposition parties joined the movement. Coincidentally, the government had a dispute with India over the trade and transit agreements that created a highly favourable situation for the uprising movement. Thousands of demonstrators and activists were arrested and many newspapers were censored and even banned. On April 6 the same year, many protesters were killed in a police action when thousands of them were heading towards the royal palace in Kathmandu. In retaliation for their demonstration, the Panchayat rulers declared a curfew but it was futile. Panchayat rulers were forced years to lift ban on political parties. Multiparty parliamentary democracy was restored in Nepal after many years of party-less autocratic rule in the country. King 
Birendra accepted his constitutional role, and an interim government that included the agitating political parties was set up to redraft the country's democratic constitution. The interim government was also responsible for holding an election in 1991. With the advent of multiparty parliamentary democracy in Nepal, the Nepali society opened up to the outside world. Nepal was then an active member of the international community and a popular tourist destination, and a major recipient of foreign aid. It progressed in all sectors of development including road, health care, education, communication, banking, and many others. Despite its opening up to the outside world, it also went through the ten-year-long Maoist insurgency that began in 1996 and that lasted with the end of the absolute monarchy in 2006; King Gyanendra was forced to abdicate the crown absolute rule following widespread protests. On May 28, 2008, Nepal was officially declared a federal democratic republic by the newly elected Constituent Assembly, ending the two and half century long monarchy.

Thus, the 1990 political change in Nepal is the starting point for the second generation of Nepali writers in English that especially came up with the emergence of two great writers: Samrat Upadhyay and Manjushree Thapa. This begs a question: Are they the canons of Nepali writing in English after Laxmi Prasad Devkota? The question is somehow tricky one and its relevance needs to be addressed by the academic circle again. These two are, however, followed by Sushma Joshi, Rabi Thapa, Sheeba Shah, Ammaraj Joshi and a few others who are still struggling to be included in the canon.

\section{CANON IN THE MAKING}

Samrat Upadhyay's Arresting God in Kathmandu and Manjushree Thapa' The Tutor of History were gained popularity and were widely read at home and abroad. They became a source of inspiration for many aspiring Nepali writers to write in English (Pun, 2013a, p. 21). Followed by them were Sushma Joshi, Sheeba Shivangini Shah and a few others. To give a few examples amongst plethora of them: Joshi published The End of the World in 2008 and Shah published Loyals of the Crown in 2005, Beyond the Illusions in 2008 and Facing My Phantoms in 2010.

In 1999, a group of Nepali poets published Voices from Nepal, the first major anthology of poems originally written in English. The poems were written by Laxmi Prasad Devkota, Abhi Subedi, Padma Prasad 
Devkota, D.B. Gurung, Tek Bahadur Karki, Laxmi Devi Rajbhandari and Arati Dahal. In 2002, edited by Deepak Thapa and Kesang Tseten and published by Martin Chautari, An Other Voice: English Literature from Nepal includes poems by Padma Prasad Devkota, Tsering Wangmo Dhompa, Wayne Amtzis, Manjul Kanchuli, E. Anne Hunkins, Kesar Lall, Abhi Subedi, Greta Rana, Tek Bahadur Karki, D.B. Gurung, Hannah Chi, and Yuyutsu R.D. Sharma. The book also consists of stories written by Samrat Upadhyay, Manjushree Thapa, Kesang Tseten, Joel Issacson, Mani Dixit, Sushma Joshi and Sunil Nepali.

New Nepal, New Voices: An Anthology of Short Stories edited by Sushma Joshi and Ajit Baral is a notable work on English literature from Nepal. This is a compilation of fifteen stories written by Nepali authors at home and abroad. The stories are by Prawin Adhikari, Wayne Amtzis, Ajit Baral, Sohan Dhakal, Smriti Ravindra, Sushma Joshi, Manju Kanchuli, Peter J. Karthak, Sunil Nepali, Greta Rana, Madan K. Limbu, Tara, Manjushree Thapa and Sanjeev Uprety. There is a list of novels, short story collections, plays, poetry collections, and non-fiction works in English published by Nepali writers in and outside Nepal. Some examples include Khem Aryal's Kathmandu Saga and Other Poems, Padma Prasad Devkota's Dawn Cycle and Other Poems, Sachendra Manandhar's It's All Written in the Stars, Abhi Subedi's Chasing Dreams, Sangita Rayamajhi's All Mothers Are Working Mothers, Mani Dixit's Over the Mountains, Rajan Prasad Pokharel's Rebels of the Mountains, Sheeba Shivangini Shah's Facing My Phantoms, Samrat Upadhyay's Buddha's Orphans, Manjushree Thapa's Seasons of Flight, Kesar Lall's Folk Tales from Nepal: Myths \& Legends, Archana Thapa's Telling a Tale, and Sanjeev Uprety and Robin Piya's IMAP Reader: A Collection of Essays on Art and Theatre in Kathmandu.

There is also a list of poems, stories, novels, plays, or travelogues from the Nepali languages translated into English, which must be considered to form part of Nepali writing in English. Himalayan Voices: An Introduction to Modern Nepali Literature is the first attempt of English translation from Nepali literature in the post-1990 era. The book is edited and translated by Michael Hutt and was published in 1991. The book is an anthology of Nepali poetry and short stories in English translation. It contains eighty poems by twenty-one poets and twenty short stories by sixteen different authors, providing "succinct and pertinent sketches of the historical, political, and 
literary contexts in which the scholars worked" (Smith, 1993, p. 164). Hutt illustrates new trends with a selection of contemporary poets and short story writers. His translated book is followed by other Nepali translators who translated Nepali literature into English, presenting before the world readers "a glimpse of the Nepalese world reflected through the creative writings" (Bhattarai, 2002, p. 68). Some of the examples of translated works include Stories of Conflict and War, Muna Madan, Contemporary Nepali Poems, The Voice of Mountains: A Collection of Modern Short Stories, Dancing Sound of Mount Everest: An Anthology of Selected Modern Nepali Poems, Women and Other Stories, The Wake of the White Tiger, Two Sisters: The Poetry of Benju Sharma and Manju Kanchuli, Poems of Nepali Women, The Country Is Yours: Contemporary Nepali Literature, and Palpasa Café.

The legacy of both writing originally in English and English translation left behind by Laxmi Prasad Devkota was and is well developed and practised by M.L. Karmacharya, Tirtha Raj Tuladhar, Daniel Khaling, Tanka Vilas Varya, Taranath Sharma, Dhruba K. Deep, Kesar Lall, Chaitanya Krishna Upadhyay, Madhusudhan Devkota and Abhi Subedi (Pun, 2013a, p. 24). This was the beginning of English translation from Nepali literature that is also as old as the tradition of writing in English in Nepal. It was "evidently guided and motivated by translational situation" (Karki, 2002, p. 54). This practice was continuously followed by Tek Bahadur Karki, Padma Prasad Devkota, Peter J. Karthak, Shanti Mishra, Shailendra Kumar Singh, Nagendra Shrama, Govinda Raj Bhattarai, H.M. Ansari, Pallav Ranjan, and Manjushree Thapa. There were also others whose English translations appeared in the form of anthologies of translated works. Though some translators such as Sondra Zeidenstein, Greta Rana, Michael Hutt, Larry Hartsell, Maya Watson, Wayne Amtzis, Yuyutsu R.D. Sharma, and Philip Pierce have helped promote the field of English translation in Nepal. But Interestingly their mother tongue is not Nepali.Nepali writing in English is not only the original works in English and English translation, it also comprises of the works in English produced in diaspora. The history of Nepali writing in diaspora is brief, but it has contributed to the enhancement of Nepali writing in English.

The above discussion indicates that creative writing activities have thrived in Nepal and therefore it is important to study them and initiate academic discourses on how and at what point English literature produced 
in Nepal diverges from other English writing in the world. Is there such a thing as Nepali writing in English? If there is, it should be discussed with Nepali English writers who have struggled hard for achieving literary height in Nepal and abroad. It is necessary to mention a name here. He should be Laxmi Prasad Devkota whose name can be considered the first canon of Nepali writing in English. There are reasons and parameters for being as such: One of them is his inclusion in the university syllabi. His English works have been included in the courses of Tribhuvan University and Pokhara University. Other two Nepali writers to be included in the Nepali English canon should be Samrat Upadhyay and Manjushree Thapa (Pun, 2013b, p. 126). They should also be considered the canons of Nepali writing in English. There are many reasons: one of them is that they are internationally acclaimed writers whose works have taken over the wider readership globally. In addition, they should be considered great writers in terms of their writing quality and thematic presentation. However, the debate over the canonization of a threesome will continue to take place in academic discourses. Of course, we can recite the names of all of them on the list even if the literary canon does not exist. It means that the works in the canon get read; they should be read by students, teachers, scholars, critics and many more readers, and so do our threesome.

\section{WHO DETERMINES THE CANON?}

The western tenets suggested that when the best ideas and thoughts can be presented in any writing, it can be said to have achieved its canonicity. In this sense, we can use these tenets to legitimize the canonicity of Nepali writing in English. But because of the emergence of a rich body of writing under postcolonial literature, the western tenets also have acquired startlingly transformed status. It is quite relevant to observe the claim made by John Marx (2004) who said: "The fact that a writer's capacity to represent a place and its people is widely considered relevant to determining canonicity suggests how dramatically postcolonial literature has changed what we mean when we say 'the canon'" (p. 85). It suggests that the canonical status of Nepali writing in English has neither questioned the western canon nor functioned as a counter-canon. But Nepali writing in English has earned critical acclaim, some Nepali writers have already attained canonical status and some others still struggling for the canon. However, there are many 
who oppose this argument primarily out of political interests, arguing that the very idea of canon does not exist in Nepali writing in English.

The ongoing debate, motivated by politics and social agenda over the nature and status of the canon has been there since the 1990s, much of which is rooted in the question of whether it is time to debate on the issue. In particular, as Abhi Subedi (1999) claims, "In Nepal, the canonicity of the postcolonial legacy continued to dominate the literary culture even without the use of English" (p. iv). He means to say that one of the main objections to a canon of Nepali writing in English is the question of authority: Who should have the power to determine what works are worth reading and teaching? In principle, the literary canon of a certain group or community is consisted of a body of works that are highly valued by literary critics, scholars, teachers, and readers. It happens because their works contain certain aesthetic value, and represent certain cultural and political values of that group or community. When they are canonized, they become institutionalized, constantly including in the syllabi and taught in the educational institutions (Pun, 2013b, p. 129). Seen in this way, the question of the status of Nepali writing in English as canonical works is yet to be determined: should they be an important part of the educational curriculum, informed by the literary canon? Such a question is debated constantly both by academics and nonacademics after the 1990 political change in Nepal.

\section{CONCLUSION}

In conclusion, the recent development indicates that Nepali writing in English is entangled in the process of canon formation. It is now high time to debate the canon in question since a discourse of canon formation in Nepali writing in English harks back as far as the early twenty-first century. As far as the inclusion of Nepali English literary texts in the educational syllabi is concerned, the growth of English writing in Nepal is significant after the 1990 political change in Nepal, especially in terms of number and quality it represents. In spite of the debate and controversy over the canonization of Nepali writers and their works in English, there will be three Nepali writers in English who will be considered the canons of Nepali writing in English. There will also be lists of other Nepali bestsellers, mustread books, and books that changed the world. But most Nepali readers would react to this list with astonishment. I would rather ask a question - why not include all Nepal writers in the canon who write in English? 
In fact, they can be considered good poets, novelists, dramatists, essayists and so on. But the question again is: do they really deserve to be one of three canons of Nepali writing in English: Laxmi Prasad Devkota, Samrat Upadhyay and Manjushree Thapa?

\section{ACKNOWLEDGEMENTS}

This paper is based on my research project on Nepali writing in English which was completed in September 2013, in financial collaboration with the Research Division of University Grants Commission (UGC), Kathmandu. I would like to thank the Research Division for its invaluable research grant.

\section{WORKS CITED}

Bhattarai, G.R. (2002). Bridging gaps in translation: An experience of rendering Nepali short fiction into English. Journal of Nepalese Literature, Art and Culture, 4(2), pp. 68-70.

Hutt, M., (Ed.) (1993). Introduction. Himalayan Voices: An Introduction to Modern Nepali Literature (pp. 1-9). Delhi: Motilal Banarsidass Publishers.

Karki, T. B. (2002). The tongues of translation. Journal of Nepalese Literature, Art and Culture, 4 (2), pp. 51-57.

Karn, S.K. (2012). This is how I can write: Towards Nepalese English literature. Journal of NELTA, 17(1-2), pp. 26-39.

Marx, J. (2004). Postcolonial literature and the western literary canon. Cambridge Companion to Postcolonial Literature (83-96). In John Marx (Ed.). Cambridge: Cambridge University Press.

Pun, M. B. (2013a). The emergence of Nepali writers in English after the 1990 restoration of democracy in Nepal. Sanothimi, Bhaktapur: University Grants Commission.

Pun, M. B. (2013b). Nepali writing in English and the 1990 people's movement in Nepal: Exploring the literary canon. Crosscurrents: A Journal of Language, Literature and Literary Theory, 2(1), pp. 114-131.

Sharma, K.C. (2011). A critical recount of English-Nepali poetic translation. Journal of Nepalese Literature, Art and Culture, 6(2), pp. 42-52. 
Smith, W. L.(1993, Jan.-Mar.). Review of Himalayan voices: An introduction to modern Nepali literature by Michael James Hutt. Journal of the American Oriental Society, 113(1), pp. 164-65.

Subedi, A. (1999). Nepali poetry in English: An insider's view. Voices from Nepal: The First Major Anthology of Poems Originally Written in English by Nepalese Poets (iii-v). Kathmandu: Shanta Malla.

Thapa, M.,(Ed.), (2009). Introduction and acknowledgements. The Country Is Yours: Contemporary Nepali Literature (v-viii). Kathmandu: The Printhouse.

Uprety, S. (2011). Nepali English writing: Problems and possibilities. Crosscurrents: A Journal of Language, Literature and Literary Theory, 1(1), pp. 221- 32.

Wilczek, P. (2012, September). The literary canon and translation: Polish culture as a case study. Sarmatian Review, pp. 1687-92. 